\title{
Border Crossing
}

January - June 2022

Volume: 12 , No: 1 , pp. $45-64$

ISSN: 2046-4436 (Print) | ISSN: 2046-4444 (Online)

journals.tplondon.com/bc

Received: 10 January 2022 Accepted: 18 February 2022

DOI: https://doi.org/10.33182/bc.v12i1.2098

\section{Bilişsel Yapının ve Sosyal Tutumların Sistemi Meşrulaştırma Eğilimine Etkisi}

\author{
Betül Dilara Şeker ${ }^{1}$ and Emine Akman Direkçi ${ }^{2}$ \\ $\ddot{O} z e t$
}

Sistemi meşrulaștırma kuram toplumda varolan sistemlerin sürdürülmesi için destekleyici nitelikteki ideolojileri ve kahp yargzlar kullanır. Bu çalısmanin temel amacı, bireylerin içinde bulunduklar sistemi meşrulaştırmada, etkili olan bilisssel yapmnn rolünü bilissel kapalıllk. ibtiyacryla, sosyal tutumlarn rolünü ise săg kanat yetkeciliği ve toplumsal baskinlık yönelimiyle incelemektir. Calısmaya, Manisa ve gevresinde yasayan, 23-55 yaş araliğnda, 203'u kadin, 191'i erkek olmak üzere toplam 394 kişi gönüllü olarak katılmusttır. Katıllmollarn sistemi meşrulaștırma eğilimlerinin çeşitli demografik değgşskenlerle (cinsiyet, yas, medeni durum, en uzun süre yaşam geçirilen yer, dini ve siyasi yönelim), bilissel

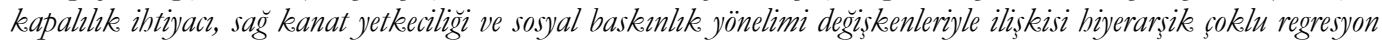
analizi ile üs adimda incelenmistir. Katılimcularn cinsiyet, medeni durum, dini ve siyasi eğilimlerinin sistemi

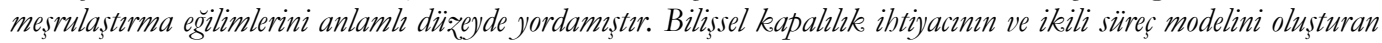

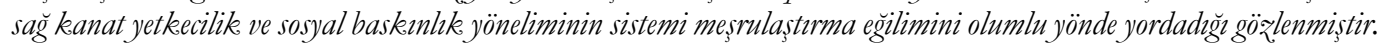

Anahtar Kelimeler: Sistemi meşrulaștırma eğilimi; Bilissel kapahllk ibtiyact; Săg kanat yetkeciliği; Sosyal baskenllk. yönelimi; İkili süreç modeli; Dini eğilim; Siyasi eğilim

\section{ABSTRACT IN ENGLISH}

\section{The Effect of Cognitive Structure and Social Attitudes on System Justification Motivation}

System legitimation theory uses supportive ideologies and stereotypes to sustain existing systems in society. The main purpose of this study is to examine the role of cognitive structure, which is effective in legitimizing the current system in which individuals live, with the need for cognitive closure, and the role of social attitudes with right-wing authoritarianism and social dominance orientation. A total of 394 people, 203 women and 191 men, between the ages of 23-55, living in Manisa and its surroundings, voluntarily participated in the study. The relationship of the participants' tendencies to legitimize the system with various demographic variables (age, gender, marital status, longest place of residence, religious and political orientation), cognitive closure need, right-wing authoritarianism, and social dominance orientation variables were analyzed in three steps by bierarchical multiple regression analysis. It was observed that the gender, marital status, religious and political tendencies of the participants significantly predicted their tendency to legitimize the system. It has been observed that the need for cognitive closure and the right wing authoritarianism and social dominance orientation, which form the dual process model, positively predict the tendency to legitimize the system.

Keywords: System justification motivation; The need for cognitive closure; Right-wing authoritarianism; Social dominance orientation; The dual-process model; Political orientation; Religious orientation

\footnotetext{
${ }^{1}$ Sorumlu Yazar: Betül Dilara Şeker, Van Yüzüncü Yıl Üniversitesi, Psikoloji Bölümü, İletişim: dilaraseker@hotmail.com.

${ }^{2}$ Emine Akman Direkçi, Manisa Celal Bayar Üniversitesi, Psikoloji Bölümü, İletişim: emi.akman@gmail.com. 


\section{Giriş}

İdeolojiler, insanların kendilerini, toplumsal yapı ve düzeni anlamalarına, yorumlamalarına, karşılaştıkları sorunları çözümlemelerine çerçeve sağlayan bilişsel bir modelidir (Mumford, ve ark., 2008). İdeolojileri epistemik, varoluşsal ve sosyal, ihtiyaçlar şekillendirmektedir (Jost, Federico ve Napier, 2009). İdeolojik eğilimle ilişkili bir psikolojik uyum mekanizması olarak değerlendirilen sistemi meşrulaştırma motivasyonu (system justification motivation); bireyin sosyal sistemi meşru, adil, durağan algilamasını sağlar ve karşılaşttğı varoluşsal, epistemik tehditlerle başa çıkmasına yardımcı olur (Kay ve ark., 2008). Çalışmada epistemik bir ihtiyaç olan bilişsel kapalılık ihtiyacı (need for cognitive closure) ve Ducitt ve ark., (2002)'nın ortaya koyduğu ikili süreç modelinde (The dual-process model) ele alınan sağ kanat yetkeciliği (rightwing authoritarianism) ve sosyal baskınlık (social dominance orientation) eğilimlerinin sistemi meşrulaştırma motivasyonu üzerindeki etkisi incelenmiştir. Ayrıca katılımcıların cinsiyeti, dini ve siyasi eğilimlerinine göre sistemi meşrulaştırma motivasyonunun farklılaşıp farklılaşmadığı da araştırilmıştır.

\section{Sistemi Meşrulaştırma}

Jost ve Banaji tarafindan geliştirilen sistemi meşrulaştırma kuramındaki sistem kavramı, sosyal, ekonomik ve politik tüm hiyerarşik sosyal düzenlemeleri kapsamaktadır (Jost ve Banaji, 1994). Kuram, varolan sistemin kendilerine veya gruplarına zarar vermesine rağmen niçin insanların bu sistemi sürdürme eğiliminde olduklarını, mevcut sistemi nasıl meşru ve adil olarak değerlendirdiklerini açıklamaktadır (Jost ve Andrews, 2011; Jolley, Douglas, ve Sutton, 2018). Sistemin meşrulaştırılması sürecinde varolan ideolojiler ve kalıp yargılar aracılığıyla özellikle dezavantajıl birey veya grup üyeleri kendi durumlarını içselleştirir ve mevcut yapıyı meşru, adil olarak algılar (Jost ve Hunyady, 2005). Sistemi meşrulaştırma süreci bilinçli bir şekilde gerçekleştiği gibi biliçdışı şekilde yerleşik kalıpyargılara verilen tepkiler olarak da gerçekleşebilir. Bilinçdışı gerçekleşen süreç, bireylerin tutum ve davranışlarını örtük olarakta etkilemekte ve şekillendirmektedir (Jost, Pietrzak, Liviatan, Mandisodza ve Napier, 2008; Jost ve ark., 2004; Jost, 2020,.3). Bu eğilim toplumdaki farklı sosyo ekonomik gruplar tarafindan paylaşılır ve yeniden üretilir (Göregenli, 2013).

Bireyler yaşadıklan toplumdaki yapıları sorgulamadan meşrulaştırma eğilimindedir çünkü bu eğilim sosyal bilişi olumlu etkilemekte ve bireylerin genel olarak mutlu hissetmesini sağlayan palyatif (geçiştirici) bir işleve sahiptir (Wakslak ve ark., 2007). İnsanlar sistemi meşrulaştırrrken hem sahip oldukları avantajlar bakımından daha kötü konumda olan grupların koşullarını haklı çıarırlar hem de sistemin farklı alanlardaki uygulamalarını da sorgulamaksızın onaylama eğilimi gösterirler (Jost, 2020:8). Bireylerin sistem hakkındaki değerlendirmeleri varoluşsal, epistemik ve sosyal ihtiyaçlarından etkilenmektedir (Jost, 1995; Jost ve Hunyady, 2005; Kay ve ark., 2008; Jolley, Douglas, ve Sutton, 2018). Bu ihtiyaçlar, sistemi meşru ve durağan olarak algılama motivasyonuna yol açtığ gibi sistemi mantıklı hale getirme, sürdürme ve koruma isteğine de neden olabilmektedir (Liviatan ve Jost, 2011; Henry ve Saul, 2006). Bireyler kendileri için dezavantajlı olsa bile varolan sosyal sistemleri daha anlaşılır, güvenli, durağan ve tahmin edilebilir algilamaya yönelik motivasyona sahiptir (Jost ve Banaji, 1994; Jost ve Hunyady, 2002; Jolley, Douglas ve Sutton, 2018). Bireyler varoldukları sistemin yapisını bozacak tehditler algıladıklarında bireyler korku ve kaygı gibi olumsuz duygular yaşarlar. $\mathrm{Bu}$ olumsuz duygulardan kurtulmak için bilinçli ya da bilinç dışı şekilde kalıp yargılar üreterek sistemi korurlar, gerginliklerini azaltır ve rahatlarlar (Jost ve Hunyady, 2002; Kay, Czaplinski

\section{Border Crossing}


ve Jost, 2009). Bir diğer ifadeyle insanların içinde bulundukları sistem tarafindan kendilerine ve diğerlerine verilen rollerin ve konumların meşruluğunu sorgulamadan, sistemin meşruluğunu sürdürmek için kendilerinin ve diğerlerinin rollerine ve konumlarına uygun olumlu veya olumsuz kalıp yargısal atıflar yaparak gerginliklerini azaltırlar (Jost ve Hunyady, 2002; Jost, 2020:4). Bu süreç avantajlı ve dezavantajlı grup üyeleri için yatıştırıcı bir işleve sahiptir. İnsanlar sistemi meşrulaştırarak sistemden daha fazla memnuniyet duyar, sistem varlığını devam ettirir, yaşam birey için anlamlı ve yordanabilir hale gelir (Jost, Glaser, Kruglanski ve Sulloway, 2003a). Eğer birey sistemde aksayan taraflarla yüzleşirse ve bu durumu düzeltmek için yapacak bir şeyi olmadığını anlarsa kendini kötü hisseder ve bu nedenle çelişki yaşar. Sistemi meşrulaştırma eğilimi bu çelişkiden kaçınma isteğinden ortaya çıkar. Bu eğilim kişi dezavantajlı grup üyesi ise yaşadığı kırgınlık, öfke ve kızgınlık duygularını; avantajlı grup üyesi ise yaşadığı suçluluk duygusunu azaltır. Sistemi meşrulaştırma eğilimi kişinin kısa vadede olumsuz duygulardan kurtulmasını sağlasa da uzun vadede sistemde olabilecek yapıc1 değişikliklere karşı dirence neden olabilir (Jost, Nosek ve Gosling, 2008a). Sistemi meşrulaştırma eğilimi değişime karşı güçlü direnç gösterse de değişimin aniden ve tamamen gerçekleştiği durumlarda birey yaşayacağ1 belirsizlikten kurtulmak için yeni sistemi meşrulaştırma süreci işlemeye başlar (Jost ve Wakslak, ve Tyler, 2008b).

Bireylerin sistemi meşrulaştırma eğiliminin yüksek olması değişime yönelik olumsuz tutumları beraberinde getirmektedir. Ayrıca avantajlı grup üyeleri sahip oldukları yüksek sistemi meşrulaştırma eğilimiyle sahip oldukları avantajlı durumları rasyonelleştirirken; dezavantajlı grup üyeleri ise kendi durumlanyla ilgili sistemi suçlamak yerine sorumluluğu kendilerinde görmekte ve eşitsizliği kabullenmektedirler (Wakslak, Jost, Tyler ve Chen, 2007).

Günlük yaşamda bireyler davranışlarının sonuçlarını tahmin etmek ve istedikleri sonuca ulaşmak için neler yapmaları gerektiğini bilmek isterler. Böylece kişi kendini güvende hisseder ve dünyanyı bilindik yer olarak alg1lar (Lerner, 1980). Kay, Jimenez, Jost (2002), bir olayın gerçekleşme olasılığı artıkça olayın sonuçlarının daha arzulanır algıladığını ifade etmektedir. Bir olayın gerçekleşme olasılığı ve sonuçlarının arzulanır algılanması arasındaki bağlantı ise sosyal dünyanın belirsizliğiyle başa çıkma mekanizmalarına dayanmaktadır. Dolayısıla, bireyler için mevcut sistemin işleyişi daha tanıdık hale gelerek, sistemin daha tahmin edilebilir sonuçlar ortaya çıkardığı izlenimi oluşmaktadır (Matthews, Levin ve Sidanius, 2009). Aynı zamanda, tutarlı ve öngörülebilir bir sosyal sistemin bireyler tarafindan tercih edilip meşrulaştırılması rahatlatıcı bir etki oluşturmaktadır. Sistemin meşrulaştırılması bireyin ideolojik inançlarını, kalıp yargılarını güçlendirmekte, süreklilik kazandırmakta ve varoluşsal tehditlere karşı sistemin adil ve doğru algılamasına neden olmaktadır (Jost ve ark., 2009). Sistemi meşrulaştırma süreci sonuç olarak bireylerin varoluşsal, epistemik, ve sosyal ihtiyaçlarını karşılaması ile bağlantılıdır (Göregenli, 2013; Jost 2020:6). Dolayısıyla, sistemi meşrulaştırma eğilimi değerlendirilirken bireylerin epistemik ihtiyaçlarının ve sosyal tutumlarnın göz önünde bulundurulması gerektiği düşünülmektedir.

Farklı araştırmalarda sistemi meşrulaştırma eğiliminin cinsiyetle ilişkili olduğu gözlenmiştir Jost ve Kay, 2005; Feygina, Jost ve Goldsmith, 2010; Karaçay, 2011; Yıldırım, 2010; Yıldırım ve Akgün, 2013). Çalışmalar sistemi meşrulaştırma eğiliminin cinsiyete göre anlamlı farklılaştığını ortaya koymuştur. Yapılan çalışmalarda erkeklerin sistemi meşrulaştırma eğiliminin kadınlara göre daha yüksek olduğu gözlenmiştir. Çalışmalar (Sönmez ve Hasta, 2021; Karaçay, 2011; Dirilen-Gümüş, 2011; Jost ve Banaji, 1994) sistemi meşrulaştırma eğiliminin dindarlıkla da ilişkili olduğu göstermektedir. Din, toplumsal düzenin sağlanmas1, 
sistemin ve statükonun meşrulaşr1lmasılyla ilişkilidir (Furseth ve Repstad, 2011: 14; Okumuş, 2003). Bireyin günlük yaşamda yaptığı meşrulaştırmalarda din önemli bir katk1 sağlar. Sistemi meşrulaştırma eğiliminin siyasi eğilimle de ilişkili olduğu farklı çalışmalarda saptanmıştır (Jost ve Thompson, 2000; Dirilen-Gümüş; 2011). Sağ siyasi eğilimli katılımcıların sistemi meşrulaştırma eğilimi puanlarının sol siyasi eğilimli katılımcılardan yüksek olduğu ortaya konulmuştur.

Farklı çalışmalarda sistemi meşrulaştırma sürecinde politik muhafazakarlık eğilimi, sosyal baskınlık yönelimi, sağ kanat yetkeciliği ve bilişsel kapalılık ihtiyacı sistemi meşrulaştırıcı yapılar olarak ele alınmıştır (Jost, Glaser, Kruglanski ve Sulloway, 2003a; Cutright ve ark., 2011). Bu çalışmada sistemi meşrulaştırma üzerinde etkili olduğu düşünülen bilişsel kapalılık ihtiyacı bilişsel yap1; sağ kanat yetkeciliği ve sosyal baskınlık yönelimi ise sosyal tutumlar (Duckitt ve Sibley, 2010) olarak ele alınmaktadır.

\section{Bilişsel Kapalılık İhtiyacı}

Kruglanski ve Ajzen'in (1983) geliştirdiği bilişsel kapalılık ihtiyac1, epistemik ihtiyaçları açıklarken kişinin yeni bilgilere nasıl yaklaştığını açıklamak için kullanılan bir kavramdır. Bilişsel kapalılık ihtiyacı, bireyin bir konuda kesin ve net bilgiye ulaşma çabası, varolan durumlarla ilgili alternatifler oluşturmaya yönelik ihtiyaçları ve karmaşı bilgiyi basitleştirerek belirsizlikten kaçınmaya yönelik bilişsel motivasyonu olarak tanımlanır (Roets ve Van Hiel, 2007; Kruglanski, 2012). Kruglanski ve Webster (1996) insanların bilgilerinin eksik ve/veya belirsiz olduğu durumlarda iki seçenekleri olduğunu ifade ederler. İlki bilişsel tamamlama ihtiyacı diğeri ise bilişsel kaçınma ihtiyacı olarak adlandırılır. Bu iki seçenek bilişsel kapalılık ihtiyacının ikili (dikotomik) yapısını ortaya koyar. Bireyin bilişsel tamamlamayı sürdürmesi ya da ondan kaçınması kararı seçimin getireceği fayda ya da maliyetine göre değerlendirilir (Webster ve Kruglanski, 1994). Bireysel ve durumsal faktörlere göre bilişsel kapalılık ihtiyac1 farklı düzeylerde hissedilir (Roets ve Van Hiel 2011). Birey kesin cevabı olmayan bir soru ile karşılaştığında epistemik bir süreç başlar. Bir cevap bulduğunda veya cevap arayışından vazgeçtildiğinde ise süreç sonlanır. Bu süreçte, kalıpyargılar ve şemalar, özellikle bilişsel kapalılık ihtyacı daha yüksek olan bireyler tarafindan daha sıklıkla kullanılır. Bireye istikrarlı bilgi sağlayan kalıpyargılar ve şemalar bireyin sabit bilgi ihtayacını karşılar ve kendini güvenli hissetmesini sağlar (Pierro ve Kruglanski, 2008).

Günlük yaşamda bazı kişiler bilgi edinme ve karar alma sürecinde yeniliklere ve değişime açık olarak bilişsel kapalılık ihtiyacından kaçınırken bazıları da bilişsel kapalılık halinde kalmakta 1srarlı yani değişime kapalıdır (Jost ve ark., 2003a; Kruglanski ve Webster, 1996). Bilişsel kapalılık ihtiyacının aciliyet (urgency) ve kalıcılık (permanence) olarak adlandırılan birbiriyle ilişkili iki ardışık eğilimle şekillendiği düşünülmektedir. İlk aşamada, kesinliği sağlayacak bilgilere, yargılara hızlı bir şekilde ulaşma ve tutunma (seizing) gerçekleşir ve birey bilişsel kapalılık eksikliğini hızla giderir, bu aşamanın ertelenmesi bireyde rahatsızlığa neden olabilir. İkinci aşamada ise bireyin yeni ve çelişkili bilgi yerine önceden sahip olduğu bilgiyi koruma eğilimi olan dondurma (freezing) süreci yaşanır ve birey benzer durumlarda kullanmak üzere ulaşılan bilgiyi saklar. Bu eğilimler bireylerin bilişsel yapılarını şekillendirir ve mevcut bilginin korunmasını sağlayarak bilişsel kapalılık eksikliğini giderir (Kruglanski, 2012). Bilişsel kapalılık ihtiyac1 beş öğeden oluşan tek boyutlu bir yap1 olarak açıklanmaktadır (Webster ve Kruglanski,1994). İlk öğe düzen tercihidir; birey düzensizlikten ve yaşamında düzeni koruma ihtiyacını ifade eder. İkinci öğe, bireyin karmaşadan kaçınmasını, yaşamında açıklık istemesini

Border Crossing 
ve belirsizlikten rahatsız olmasını ifade eden belirsizlikten rahatsızlıtır. Üçüncüsü, bireyin gelecekle ilgili tahmin edemediği değişikliklerden kaçınmasını, öngörülebilir ve tutarlı bilgi ihtiyacını kapsayan tahmin ihtiyacıdır. Dördüncü öğe bireyin yeni bilgilere karşı isteksiz olmasını, alternatif fikirlere güven duymamasını, mücadeleden kaçınmasını ifade eden dar görüşlülüktür. Beşinci öğe olan kararlılık ise; bireyin kararsızlıktan kaçınmasını, seçim ve yargılarında hızlı karar verme ihtiyacıdır (Calogero ve ark., 2009). Bilişsel kapalılık ihtiyacı güçlü olan bireylerin kesin ve kararlı bilgiye sahip olduğu ve bu bilgiyi değiştirme konusunda isteksiz oldukları, yetke ve hiyerarşiyle ilgili inançlarının durağan olduğu ve normlara karşı çıkma davranışlarının ise daha düşük olduğu, yaşamlarında düzene önem verdikleri, hızlı karar verme eğiliminde oldukları, belirsizliğe ve karmaşıklığa tolerans düzeylerinin düşük olduğu ve aynı zamanda değissime de kolay uyum sağlayamadıkları ifade edilmektedir (Duriez, 2003; Chirumbolo ve Areni, 2010; Roets ve Soetens, 2010; Kruglanski ve ark., 2007; Jost ve Kay, 2005). Bilişsel kapalılık ihtiyacı düşük olan bireylerin ise belirsizlikten rahatsız hissetmediği, farklı seçeneklere açık oldukları ve karar verme sürelerinin uzun ve esnek bir düşünce yapısına sahip oldukları söylenebilir (Calogero ve ark., 2009; Kruglanski ve Webster, 1996).

Bilişsel kapalılık ihtiyacı; bireylerin bilişsel stilini, sosyal çevrelerine yönelik değerlendirmelerini ve tepkilerini etkilemektedir (Chirumbolo, 2002; Kossawska ve Van Hiel, 2003). Bilişsel kapalılık ihtiyacının politik eğilimler (Van Hiel ve Mervielde, 2004) dogmacılık (Francis, 2001), yetkecilik (Duck ve Hunsberger, 1999), politik muhafazakarlik (Jost ve ark., 2003a), konformite ve norma bağllık (Fu ve ark., 2007) gibi farklı kavramlarla ilişkili olduğu ortaya konulmuştur. Buna ek olarak bilişsel kapalılık ihtiyacının ideoloji ile bağlantılı tutumlar, yargılar ve eğilimlerle de ilişkili kavramlar olduğu da bilinmektedir (Jost ve ark., 2009).

\section{Sağ Kanat Yetkeciliği}

Duckitt ve ark. (2002)'nın ikili süreç modelinde farklı güdülerle ilişkili değerlendirilen sağ kanat yetkeciliği ve sosyal baskınlık yönelimi sistemi meşrulaştırma eğilimini anlamada ve açıklamada kullanılan önemli kavramlardır. Modelde dünyayı tehlikeli bir yer olarak algılamanın sonucu sosyal düzen ve durağan geleneklere duyulan ihtiyaç sağ kanat yetkeciliğini; dünyayı bir rekabet ortamı olarak algılamanın sonucu güç kazanmak için savaşma ve diğerleri üzerinde baskınlık kurma ihtiyacı ise sosyal baskınlık eğilimini güdülediği ve sosyal tutumları etkilediği ifade edilmektedir (Duckitt ve Sibley, 2013) .

Altemeyer (1996) tarafından geliştirilen sağ kanat yetkecilik kuramına göre yetkecilik sosyalleşme süreci içinde aile, akran etkileşiminde maruz kalınan itaat etme, saldırganlık deneyimlerine, durumsal faktörlere ve sosyal öğrenmelere dayanmaktadır. Sağ-kanat yetkeciliği normlara, gelenek ve değerlere sorgulamadan bağl1lik, otoriteye karşı sorgusuz itaat ve normları ihlal edenlere karşı saldırganlık gösterme eğilimi olarak tanımlanır (Altemeyer, 2003). Yetkeci bireyler otoritenin kesin doğruyu bildiğini, mevcut otoriteye itaat edilmesi ve sayg1 duyulması gerektiğini düşünürler. Bu nedenle otoriteye muhalefet veya eleştiri tehdit olarak algılanır. Otoritenin gerektiğinde sansür uygulaması, keyfi davranışlarda bulunması ya da saldırgan davranışlar sergilemesi onaylanabilir (Altemeyer, 2003). Bireyin sahip olduğu sağ kanat yetkecilik düzeyi, dünyanın tehlikeli ve tehditlerle dolu bir yer olarak algilanma düzeyini ortaya koyar. Birey düzen için varolan örf, gelenek, görenek ve kuralları sorgusuz bir şekilde kabul eder. Ayrıca bu kurallar davranışlar için referans noktası olarak kabul edilir dolayısıyla değişime karşı direnç gösterilir (Perry ve Sibley, 2010). Özetle să̆ kanat yetkecilik, otoriteyi kayıtsız şartsız kabul etme eğilimini, sosyal normlara bağlılı̆̆1, otoritenin düşüncelerinin ve 


\section{Bilissel Yapınn ve Sosyal Tutumlarn Sistemi Messulaștırma Eğilimine Etkisi}

davranışlarının meşrulaştırılmasını, otoriteye karşı gelen birey ya da grupların cezalandırılmasını böylece, mevcut sistemin sürdürülmesini ifade etmektedir (Duriez ve Soenens, 2009). Jost ve Hunyady (2005) sağ kanat yetkeciliği yüksek olan bireylerin kalıp yargılar ve statükoyu destekleyerek sistemi meşrulaştırdığını ifade eder. Ayrıca farklı çalışmalarda sağ kanat yetkecilik düzeyi yüksek olan bireylerin dini eğilimleri yüksek olduğu; sosyal, ekonomik eşitsizlikleri ve demokratik olmayan tutumları destekledikleri; dış gruplara baskı kurma; saldırganlık; ülkedeki enflasyon, işsizlik, suç oranlanı gibi tehditleri daha yüksek algılama, sosyal değişime direnç gösterme ve katı bir bilişsel yapıya sahip olma eğiliminde oldukları saptanmıştır (Canetti-Nisim ve Beit-Hallahmi, 2007; Hasta ve Dönmez, 2009; Onraet, Hiel ve Cornelis, 2013; Poteat ve Spanierman, 2010; Jost ve ark., 2014).

\section{Sosyal Baskınlık}

Sosyal baskınlık yönelimi ise sistemi meşrulaştırmaya ilişkin sosyal tutumları açıklamak amacıyla ele alınan bir diğer kavramdır. Sosyal baskınlık yönelimi grup temelli önyargı ve baskı sonucu hayatın her alanında karşımıza çıkmaktadır. Dünya gruplararası güç mücadelesinin yaygin olduğu rekabetçi bir ortam olarak değerlendirmektedir (Sidanius, Pratto, van Laar ve Levin, 2004). Kavram ilk olarak, toplumdaki bir veya bir kaç grubun gücünü korumak amacıyla diğerleri üzerinde baskı kurma ve bireyin kendi grubunun toplumda varolan diğer gruplardan baskın olması eğilimi olarak tanımlanmıştır. Ancak bir kişilik değişkeni olan kavramın tanımı süreç içinde yeniden revize edilmiştir. Sosyal baskınlık yönelimi bireyin kendi grubunun/gruplarının mevcut hiyerarşik yapı içindeki durumundan bağımsız olarak, varolan geleneksel rolleri pekiştirme, gruplar arası eşitsizliği devam ettirme, mevcut hiyerarşik sosyal sistemleri koruma ve sürdürme eğilimi olarak ifade edilmiştir (Jost ve Hunyady, 2005). Kuram toplumdaki gruplar arasında hiyerarşik yapıya bağlı ortaya çıkan gruplararası eşitsizliği ve sınırlı sayıdaki üst grubun diğer gruplar üzerindeki baskınlığını destekleme eğiliminini inceler (Pratto, Sidanius ve Levin, 2006). Bu hiyerarşik yapı içinde egemen ve baskın gruplar sayıca az insan veya gruptan oluşur. Baskın gruplar otorite, güç, geniş kaynaklar, eğitim, kaliteli yaşam gibi bir çok avantaja sahiptirler. Alt gruplar ise sayıca fazla insan veya gruptan oluşur ve baskın grupların sahip olduğu avantajlara sahip değillerdir (Sidanius, Levin, Liu ve Pratto, 2000). Sistem içinde varolan hiyerarşik yapıların oluşumu ve sürdürülmesinde toplum tarafindan paylaşılan ideolojiler, inanışlar, kalıpyargılar vb. meşrulaştırıcı mit olarak önemli role sahiptir. Meşrulaştırıcı mitler, grup temelli eşitsizlikleri akılcı ve ahlaki olarak destekleyen meşrulaştırıcı mitler biyerarşiyi artıran meşrulaștırı mitler (örn.1rkçılık, cinsiyetçilik, kadercilik); gruplar arası eşitliği destekleyenler ise biyerarsizi azaltan meşrulaştırı mitler (örn. insan hakları evrensel bildirisi, humanizm, feminizm) olarak adlandırılır. Birey hiyerarşiyi artıran meşrulaştırıcı mitleri destekliyorsa bireyin sosyal baskınlık eğilimi yüksek, hiyerarşiyi azaltan meşrulaştırıcı mitleri destekliyorsa sosyal baskınlık eğilimi düşüktür (Pratto, Sidanius ve Levin, 2006). Önceleri tek boyutlu değişken olarak değerlendirilen sosyal baskınlık eğilimi, grup temelli baskınlık (group-based dominance) ve eşitliğe karşı olma (opposition to equality) olarak adlandırılan iki boyutlu yapıda olduğu ortaya konulmuştur (Jost ve Thompson, 2000). Yüksek düzeyde sosyal baskınlık yönelimi olan bireyler politik muhafazakarlığa ilişkin ideoloji ve inançları meşrulaştırarak hiyerarşiyi güçlendirip korumaktadır (Pratto ve ark., 2006). Öte yandan Kay ve Jost (2003) düşük sosyal baskınlık yönelimi olan bireylerin eşitlik ve denge alg1ları aracılı̆̆ıyla statükoyu kısmen meşrulaştırdıklarını belirtmiştir.

Sistemi meşrulaştırma kuramı 'Türkiye' deki farklı çalışmalarda sağ kanat yetkeciliği, sosyal baskınlık yönelimi, adil dünya inancı kavramlanı ile birlikte çalışılmıştır (Örn; Göregenli, 2004; 
Güldü ve Kart, 2009; Hasta ve Dönmez, 2009) ancak sistemi meşrulaştırma kuramı epistemik bir ihtiyaç olan bilişsel kapalılık ihtiyacıyla birlikte ele alınmamıştır.

Çalışmada, sistemi meşrulaştırma kavramı ile ilişkili olduğu düşünülen bilişsel kapalılık ihtiyacı bilişsel yapı olarak, sağ kanat yetkeciliği ve sosyal baskınlık yönelimi ise sosyal tutum olarak iki ayrı çerçevede ele alınmıştır. Çalışmanın amacı bilişsel kapalılık ihtiyacının, să̆ kanat yetkeciliğinin ve sosyal baskınlık yöneliminin sistemi meşrulaştırma eğilimi üzerindeki yordayıcı etkilerinin incelenmesidir. Çalışmada bilişsel kapalılık ihtiyacı ve ikili süreç modeli çerçevesinde sınanacak olan denenceler aşağıda sıralanmıştır.

1. Katılımcılanın sistemi meşrulaştırma eğilimleri cinsiyet, sahip olduklarını dini ve siyasi yönelimlere göre anlamlı şekilde farklılaşmaktadır.

2. Katılımcıların bilişsel kapalılık ihtiyacı, săg kanat yetkeciliği ve sosyal baskınlık yönelimi sistemi meşrulaştırma eğilimini olumlu yönde yordamaktadır.

\section{Yöntem}

\section{Örneklem}

Bu çalışma 2016-2017 yılları arasında Manisa ve çevresinde yaşayan basit rastlantısal örnekleme yoluyla seçilmiş 203 (\%51.5) kadın, 191’i (\%48.5) erkek olmak üzere 394 kişi gönüllü olarak katılmıştır. Yaşları 23 ile 55 arasında değişen katılımcıların yaş ortalaması 33.67 $(S=9.31)$ olarak bulunmuştur. Çalışmada yer alan katılımcıların $\% 55$ 'inin bekar, $\% 41$ 'inin evli, \%4'ünün ise ayrilmış/boşanmış olduğu görülmüştür. Katılımcıların \%7'sinin köy, \%10’unun ilçe, \%57'sinin şehir ve \%27'sinin ise büyükşehri en uzun süreli yaşadıkları yerleşim birimi olarak ifade ettikleri görülmüştür. Ayrıca, katılımcıların kendi dini ve siyasi eğilimlerini yedi dereceli ölçek üzerinden değerlendirmeleri istenmiş ve sonuç olarak katılımcıların dini eğilimlerinin ortalama $4.66(S=1.50 ; 1=$ hiç inançlı değil, $7=$ çok inançlı); siyasi eğilimlerinin ise ortalama $3.85(S=1.43 ; 1=$ aşı11 sol, $7=$ aşırı sağ $)$ olduğu saptanmıştır.

\section{Veri Toplama Araçları}

Çalışmada beş bölümden oluşan soru formu kullanılmıştır. Soru formunda, demografik bilgi formu, Sistemi Meşrulaştırma Ölçeği, Bilişsel Kapalılık İhtiyacı Ölçeği, Sağ Kanat Yetkeciliği Ölçeği ve Sosyal Baskınlık Yönelimi Ölçeği yer almıştır.

Demografik Bilgi Formu. Formunun ilk kısmında cinsiyet, yaş, medeni durum ve en uzun süre yaşadıkları yerleşim birimine (köy, ilçe, şehir, büyükşehir) yönelik sorular yer almıştır. Ayrıca, katılımcıların dini ve siyasi eğilimlerini değerlendiren iki soruya da yer verilmiştir. Katılımcılara "Kendi dini inanç düzeyinizi nasıl değerlendiriyorsunuz?" (1 = hiç inançlı değil, 7 = çok inançli) ve "Kendinizi siyasi görüşleriniz açısından nasıl değerlendiriyorsunuz?" (1 = aşırı sol, 7 = aşırı sağ) şeklinde iki soru yöneltilmiştir.

Sistemi Meşrulaştırma Ölçĕ̆i. Kay ve Jost (2003) tarafindan geliştirilen ölçeğin Türkçe uyarlaması Yıldırım (2010) tarafından yapılmıştır. Ölçek 8 maddeden (örnek madde: İzlenen çoğu politika, toplumun çoğunluğunun yararınadır) oluşmaktadır. Elde edilen ölçümler 7 dereceli Likert tipinde ( $1=$ Kesinlikle katılmıyorum; $7=$ Kesinlile katıliyorum $)(\alpha=.67)$ ölçek ile değerlendirilmiştir. Bu çalışmada ölçeğe ait Cronbach alfa iç tutarlık katsayısı .82 olarak hesaplamıştır. Bireylerin ölçekten aldığı puan arttıkça sistemi meşrulaştırma düzeyleri artmaktadir. 
Bilişsel Kapalılık İhtiyacı Ölçeği. Ölçek Webster ve Kruglanski (1994) tarafindan geliştirilmiştir. Türkçe uyarlaması ise Şeker ve Akman (2015) tarafindan yapılmıştır. Uyarlama çalışmasına göre 36 maddeden oluşan ve 6 dereceli Likert $(1=$ Kesinlikle katılmıyorum, $6=$ Kesinlikle katılıyorum) tipinde olan ölçeğin düzen tercihi (örnek madde: Her şey için bir planın ve yerin olmasından hoşlanırım) $(\alpha=.78$ ), belirsizlikten rahatsızlık (örnek madde: Belirsiz durumlardan hoşlanmam) ( $\alpha=.61$ ), tahmin ihtiyacı (örnek madde: Ne yapacağ1 belli olmayan arkadaşlarımın olmasından hoşlanırım) ( $\alpha=.66$ ), dar görüşlülük (örnek madde: Karşılaştığım sorunların olası pek çok çözümünü daima görürüm) $(\alpha=.55)$ ve kararlılık (örnek madde: Önemli kararları son ana kadar bekletme eğilimindeyim) ( $\alpha=.60)$ olmak üzere beş boyutu vardır. Ölçeğin tamamı için hesaplanan Cronbach alfa iç tutarlık katsayısı .72'dir. Bu çalışmada her boyut için hesaplanan Cronbach alfa iç tutarlılık katsayısı düzen tercihi için .69; belirsizlikten rahatsızlık için .62; tahmin ihtiyacı için .60; dar görüşlülük için .57; kararlılık için .57, ölçeğin tamamı için ise .79 olarak hesaplanmıştır. Ölçekten alınan yüksek puanlar bilişsel kapalılık ihtiyacının arttığına işaret etmektedir.

Să̆ Kanat Yetkeciliği Ölçeği. Ölçek Altemeyer (1996) tarafindan geliştirilmiştir. Türkçe uyarlaması Güldü (2011) tarafindan yapılmıştır. Uyarlama çalışmasına göre 18 maddeden oluşan ve 9 dereceli Likert tipinde ( 1 = kesinlikle katılmıyorum; 9 = kesinlikle katılıyorum) değerlendirilmiştir. Ölçeğin yüksek düzey sağ kanat yetkecilik (örneğin, "Eski moda adetler ve değerler hala en iyi yaşama biçimini gösteriyor”) ( $\alpha=$. 82) ve düşük düzey sağ kanat yetkecilik (örneğin, "Birçok kişiyi tedirgin etse bile ülkemizin, geleneksel uygulamalara karşı çıkma cesareti gösterebilen özgür düşünceli bireylere ihtiyacı var”) $(\alpha=.78)$ olmak üzere iki boyutu bulunmaktadır. Güldü tarafindan hesaplanan ölçeğin tamamı için hesaplanan Cronbach alfa iç tutarlık katsayısı .85’tir. Bu çalışmada ölçeğin tamamı için hesaplanan Cronbach alfa iç tutarlık katsayısı .85 iken yüksek sağ kanat yetkeciliği boyutunun Cronbach alfa iç tutarlık katsayısı .81, düşük sağ kanat yetkeciliği boyutunun Cronbach alfa iç tutarlık katsayısı .77'dir. Ölçekten alınan puanlar arttıkça bireylerin yetkecilik düzeyleri artmaktadır.

Sosyal Baskınlık Yönelimi Ölçeği. Ölçek Sidanius, Pratto ve Bobo (1994) tarafindan geliştirilmiştir ve Türkçe'ye uyarlama çalışması Karaçanta (2002) tarafından yapılmıştır. Ölçek 16 maddeden oluşmaktadır (örneğin, "Belirli grupların en üstte diğer grupların en altta olması belki iyi bir şeydir”) oluşmaktadır. Ölçek maddeleri 7 dereceli Likert tipi (1 = hiç katılmıyorum, 7 = tamamen katılıyorum) ölçek üzerinden değerlendirilmektedir. Karaçanta tarafindan hesaplanan ölçeğin tamamı için hesaplanan Cronbach alfa iç tutarlık katsayısı .85'tir. Bu çalışmada Cronbach alfa iç tutarlık katsayısı .80 olarak bulunmuştur.

\section{Işlem}

Çalışmada Manisa ve çevresinde yaşayan katılımcılara yarı tesadüfi örneklem yöntemiyle ulaşılmıştır. Katılımcılar araştırmaya gönüllülük esasına dayalı olarak katılmışlardır. Önce katılımcılara çalışma hakkında bilgi verilmiş ve soru formu uygulanmıştır. Katılımcılara sorulardan rahatsız oldukları durumda çalışmayı yarıda bırakabilecekleri, çalışmadan elde edilen verilerin gizli tutulacağı, verilerin çalışma dışında herhangi bir amaçla kullanılmayacağ1 belirtilmiştir. Araştırmaya Bilgilendirilmiş Gönüllü Olur Formu’nu onaylayan kişiler katılmıştır. Çalışmadan elde edilen verilerin analizi öncesi veri girişinin doğruluğu ve veri dağılımının normalliğe uygunluğu test edilmiş ve uç değerler veri setinden çıkarılıp verilerin normal dağılım gösterdiği belirlenmiştir. Elde edilen veriler SPSS paket programı ile analiz edilmiştir. 


\section{Bulgular}

Çalışmanın amaçlarından biri katılımcıların sistemi meşrulaştırma düzeylerinin cinsiyet, dini ve siyasi eğilimlerine göre farklılığının incelenmesidir. Çalışmada ilk olarak, değişkenler arasındaki ilişkileri belirlemek için Pearson tekniği kullanılarak korelasyon analizi yapılmıştır. Sistemi meşrulaştırmayı yordayan değişkenleri belirlemek için aşamalı hiyerarşik regresyon analizi gerçekleştirilmiştir.

\section{Korelasyon Analizine İlişkin Bulgular}

Araştırmada yer alan değişkenler arasındaki ilişkileri belirlemek için yapılan korelasyon analizi sonuçları Tablo 1'de gösterilmiştir.

Sistemi meşrulaştırmanın, siyasal görüş, dini inanç, bilişsel kapalılık, sağ kanat yetkecilik ve sosyal baskınlık ile pozitif yönde ve anlamlı olarak ilişkili olduğu görülmektedir. Bu bulgu, sağ siyasal görüş ve inanç düzeyi arttıkça sistemi meşrulaştırma düzeyinin arttığını göstermektedir. Ayrıca bilişşsel kapalılık ihtiyacı, sağ kanat yetkecilik ve sosyal baskınlık düzeyi arttıkca sistemi meşrulaştırma düzeyinin de arttığ1 gözlenmiştir. Değişkenler arasında gözlenen diğer ilişkiler anlamlı değildir.

\section{Sistemi Meşrulaştırma Eğilimine Yönelik Yordayıcı Etkiler}

Çalışmanın temel amacı, katılımcıların bilişsel kapalılık ihtiyacı, sağ kanat yetkeciliği ve sosyal baskınlık yönelimi değişkenlerinin sistemi meşrulaştırma eğilimleri üzerindeki yordayıc1 etkisinin belirlenmesidir. Bu amaçla katılımcıların sistemi meşrulaştırma eğilimlerini yordayan değişkenleri ortaya koymak için sistemi meşrulaştırma eğilimi ölçeğinden aldıkları puanlara hiyerarşik çoklu regresyon analizi uygulanmıştır (Tablo 2). Cinsiyet (kadın ve erkek), medeni durum (evli ve bekar), en uzun süre yaşam geçirilen yer (köy, ilçe, şehir ve büyükşehir) gibi demografik değişkenleri kategorik değişkenler olarak toplandığ1 için regresyon analizine sokulmadan önce yapay kodlama (dummy coding) gerçekleştirilmiş, yaş, dini ve siyasi yönelim değişkenleri ise sürekli değişkenler olarak analize dahil edilmiştir.

Sistemi meşrulaştırma eğiliminin yordanan ve demografik değişkenler ile sağ kanat yetkeciliği, sosyal baskınlık yönelimi ve bilişsel kapalılık ihtiyacının yordayıcı değişkenler olarak ele alındığ1 hiyerarşik regresyon analizi üç aşamada gerçekleştirilmiştir. İlk aşamada bireylerin sistemi meşrulaştırma eğilimleri üzerinde etkili olduğu düşünülen cinsiyet, yaş, medeni durum, en uzun süre yaşam geçirilen yer ile dini ve siyasi eğilimleri gibi demografik değişkenler kontrol amacıyla modele dahil edilmiştir. İkinci aşamada sistemi meşrulaştırma eğilimini yordamada bilişsel kapalılık ihtiyacı modele dahil edilmiştir. Son aşamada ise sağ kanat yetkeciliği ve sosyal baskınlık yönelimi analize birlikte dahil edilmiştir.

Regresyon analizi sonuçlarının yer aldığı Tablo 2 incelendiğinde demografik değişkenlerin yer aldığı ilk regresyon modelinin katılımcıların sistemi meşrulaştırma eğilimi puanlarını anlamlı düzeyde yordadığ1 görülmektedir, $R^{2}=.18, F_{(11,371)}=8.33, p<.01$. Bu değişkenlerden cinsiyet, medeni durum, dini ve siyasi yönelim değişkenlerinin sistemi meşrulaştırma eğilimi ölçeği puanlarındaki varyansı açıklayan yordayıcılar olduğu gözlenmiştir. Katılımcıların erkek olmasının sistemi meşrulaştırma eğilimini olumlu yönde etkilediği bulunmuştur. Bekar olma durumunun ise katılımcıların sistemi meşrulaştırma eğilimini üzerinde olumsuz bir etkisi olduğu görülmüştür. Ayrıca, sağ siyasi eğilimli olmanın ve daha yüksek dini inanç düzeyinin sistemi meşrulaştırma eğilimini arttıran yordayıcılar olduğu gözlenmiştir. Öte yandan, yaş, en 
uzun süre yaşam geçirilen yer, değişkenlerinin sistemi meşrulaştırma eğilimi ile ilişkisinin anlamlı olmadı̆̆ı ortaya konulmuştur.

Regresyon modeline ikinci aşamada bilişsel kapalılık ihtiyacına ait düzen tercihi, belirsizlikten rahatsızlık, tahmin ihtiyacı, kararlılık ve dar görüşlülük boyutlarının dahil edilmesiyle, sistemi meşrulaştırma eğilimi puanlarındaki toplam varyasın \% 23'ünün açıklandığı gözlenmiştir, $R^{2}=$ $.23, F_{(16,379)}=8.17, p<.01$. Bilişsel kapalılık ihtiyac1 ölçeğinin düzen tercihi, belirsizlikten rahats1lık, tahmin ihtiyac1 ve kararlılik boyut puanlarının modelde anlamlı bir yordayıc1 etkiye sahip olduğu bulunmuştur. Dar görüşlülük alt boyutunun ise sistemi meşrulaştırma eğilimini yordamada anlamlı bir etkiye sahip olmadığı saptanmıştır.

Regresyon analizinin üçüncü aşamasında sağ kanat yetkeciliği ve sosyal baskınlık yönelimi değişkenlerinin de dahil edildiği model ile açıklanan varyans \% 43'a yükselmiştir $\left(R^{2}=.43\right.$, $\left.F_{(19,379)}=15.84, p<.01\right)$. Bulgular, yüksek düzey sağ kanat yetkeciliğinin sistemi meşrulaştırma eğilimi düzeylerini olumlu yönde yordadı̆̆ını göstermiştir. Benzer şekilde düşük sağ kanat yetkeciliği alt boyutundan yüksek puan almanın sistemi meşrulaştırma eğilimi üzerinde olumsuz bir etkisi olduğu bulunmuştur. Ek olarak, yüksek düzeyde sosyal baskınlık yönelimi olan katılımcıların sistemi meşrulaştırma eğilimi düzeylerinin de yüksek olduğu görülmüştür. Sağ kanat yetkeciliği ve sosyal baskınlık yöneliminin modele dahil edilmesiyle birinci ve ikinci aşamada anlamlı olan cinsiyet ve dini eğilim değişkenlerinin ikinci aşamada sistemi meşrulaştırma eğilimi düzeyiyle anlamlı ilişkisi bulunmadığı gözlenmiştir.

\section{Tartışma}

Bu çalışmada sistemi meşrulaştırma eğilimi ile ilişkili bilişsel yap1 ve sosyal tutumlarla ilgili değişkenlerin incelenmesi amaçlanmıştır. Sistemi meşrulaştırma eğilimini etkilediği düşünülen bilişsel yap1, bilişsel kapalılık düzeyi; sosyal tutumlar ise sağ kanat yetkeciliği ve sosyal baskınlık yönelimi bağlamında değerlendirilmiştir (Corr, Hargreaves-Heap, Tsutsui, Russell ve Seger, 2013). Sistemi meşrulaştırma eğiliminin; bilişsel kapalılık ihtiyacı, sağ kanat yetkeciliği ve sosyal baskınlık yönelimi değişkenlerinin ilişkili kavramlar olduğunu ortaya koyan farklı çalışmalar bulunmaktadır (Hasta ve Dönmez, 2009; Jost ve ark., 2003a; Jost ve ark., 2003b; Van Hiel, Pandelaere ve Duriez, 2004). Çalışmada sistemi meşrulaştırma eğilimi üzerinde etkili olabilecek bilişsel yapı ve sosyal tutumların etkisinin birlikte incelenmiştir. Çalışma sonuçları katılımcıların sistemi meşrulaştırma eğilimlerinin cinsiyet, dini ve siyasi eğilimlerine göre farklılaştığını göstermiştir. Bilişsel kapalılık ihtiyacının sistemi meşrulaştırma eğilimi üzerinde olumlu yordayıcı bir etkisi olduğu, sadece dar görüşlülük boyutunun süreci yordayıcı etkisinin olmadığı gözlenmiştir. Ayrıca sağ kanat yetkeciliği ve sosyal baskınlık yöneliminin de sistemi meşrulaştırma eğilimini olumlu yönde yordadığı ortaya konulmuştur.

Çalışmada sistemi meşrulaştırma eğilimine yönelik yordayıcıların belirlenmesi için gerçekleştirilen çoklu regresyon analizi sonucu sosyo-demografik değişkenlerin sistemi meşrulaştırma eğilimi üzerinde yordayıcı etkilerinin olduğu ortaya konulmuştur. Erkek katılımcıların kadınlara göre daha yüksek sistemi meşrulaştırma eğilimine sahip olduğu bulunmuştur. Bu durumun da Jost ve Kay (2005) tarafindan gerçekleştirilen çalışmadan elde edilen erkeklerin sistemi meşrulaştırma eğiliminin daha yüksek olduğu bulgusuyla tutarlı olduğu gözlenmiştir. Bu durumun kadın ve erkeklerin cinsiyet şemaları ve bu şemalara bağlı olarak şekillenen toplumsal cinsiyet rollerinin, bireyin mevcut toplumsal yapıdaki eşitsizlikleri içselleştirmesi sonucu sistemi meşrulaştırma eğilimindeki cinsiyet farklılıklarıyla ilişkili olduğu düşünülmektedir (Jost ve Kay, 2005). Kadın ve erkeklerin cinsiyet rollerini benimsemesi

\section{Border Crossing}


sürecindeki farkl1lıkların toplumdaki statükonun kabulü konusunda farklı tutumlar geliştirmelerine ve sistemi meşrulaştırma eğilimindeki cinsiyet farklılıklarına da temel oluşturduğu düşünülmektedir. Erkeklerin statükoyu daha fazla destekleyip daha yüksek düzeyde sistemi meşrulaştırma eğilimi göstermesi, toplumda avantajlı durumdaki grubun üyelesi olmaları ile açıklanabilir (Rudman ve Goodwin, 2004; Feygina, Jost ve Goldsmith, 2010). Aynı zamanda bir diğer sosyo-demografik değişken olan medeni durum ele alındığında, evlilikle sistemi meşrulaştırma arasında olumlu bir ilişki olduğu, evli bireylerin, bekar, dul ve eşinden ayrı yaşayan bireylerle karşılaştırıldığında daha yüksek düzeyde sistemi meşrulaştırma eğilimine sahip oldukları bulunmuştur. Bu durum evlilik gibi bağlllık belirten ilişkilerin bireylere düzen ve kontrol duygusu sağlamasıyla açıklanabilir (Day, Kay, Holmes ve Napier, 2011). Japonya ve Çin gibi toplulukçu kültürlerde bekarların daha düşük konumda algıllandığ1 bilinmektedir (Cuddy, Fiske ve Glick, 2004). Benzer şekilde toplulukçu bir kültür olan Türkiye'de de evlilik kişiler için daha üst bir grup üyeliği olarak algılanmakta ve kişilerin sistemi daha fazla destekleyerek sürdürme eğilimini arttırmaktadır.

Dini ve siyasi eğilimler bireyin günlük yaşamının bir çok alanını düzenlemekte önemli rol oynayan faktörlerdir (Jost, 2006). Bu yüzden sistemi meşrulaştırma eğilimleri değerlendirilirken bu iki temel faktörün etkisi de incelenmiştir. Çalışma bulguları sistemi meşrulaştırma eğiliminin dini ve siyasi eğilimlere göre farklılaştı̆̆ını ve bu iki değişken tarafından anlamlı biçimde yordandığını göstermiştir. Sosyal yaşamın daha güvenli, tahmin edilebilir ve adil bir yer olduğuna inanma ihtiyacı doğrultusunda şekillenen dini eğilimlerin sistemi meşulaştırma eğilimi üzerindeki etkisi değerlendirildiğinde, inanç düzeyi yüksek olan bireylerin daha fazla sistemi meşrulaştırma eğilimine sahip olduğu ortaya konulmuştur. Bireyin inancına bağlılı̆̆1 ve inancının kapsadığı değerleri benimsemesi sistemi meşrulaştırma eğilimini arttıran bir etkiye sahiptir (Jost ve ark., 2009b: 119). Sistemde benzer uygulamaların sürekliliği sistemin daha meşru algılanmasına neden olmaktadır. Bireyin siyasi eğilimi belirsizlik ve tehditi azaltma ihtiyacının yansıması olarak varolan sistemin devam ettirilip korunmasında etkili olmaktadır (Jost, 2009b: 121). Geleneksel yap1 ve sistemin devamıyla güçlü ilişkisi olan sağ siyasi eğilimlerin, sistemin meşrulaştırılmasında temel rol oynadığı ortaya konulmuştur (Jost ve Hunyady, 2005). Benzer şekilde bu çalışmada da, să̆ siyasi eğilimlerin sistemin meşrulaştırılmasını arttıran bir etkisi olduğu gözlenmiştir.

Mevcut sistemin desteklenmesi bireyin kendini güvende hissetmesini, yaşamını durağan ve kontrol altında algılamasını, sosyal yapıda ilişkilerini geliştirip sürdürmesini sağlamaktadır (Jost, Wakslak ve Tyler, 2008b). Birey bu temel motivasyonları doğrultusunda sistemi meşrulaştırarak desteklerler (Jost, Ledgerwood ve Hardin, 2008c). Bu motivasyonlardan biri olan temel epistemik ihtiyaçları açıklamada kullanılan (Jost ve ark., 2003a) bilişsel kapalılık ihtiyacının da sistemi meşrulaştırma eğilimine yönelik yordayıcı etkisi incelenmiştir (Jost ve ark., 2003a). Bilişsel kapalılık ihtiyacının sistemi meşrulaştırma eğiliminin etkili bir yordayıc1 olması temelinde, insanların günlük bilgi edinme sürecinde herkes tarafindan paylaşılan kalıpyargıları kullanarak yaşanan belirsizliği sonlardırma isteği bulunduğu düşünülmektedir. Bir diğer ifadeyle mevcut sistemler, kişi tarafından bilişsel olarak değerlendirilmeden, egemen yapı referans alınarak, daha az sorgulayıc1, şekilde meşrulaştırılmaktadır. Bilişsel kapalılık ihtiyacının dargörüşlülük boyutunun sistemi meşrulaştırma sürecini yordamada etkili olmadı̆̆1 gözlenmiştir. Belirsizlik ve değişim bireyler için farklı durumlarda farklı tepkilere neden olduğundan, bireylerin mevcut sosyal yapıdaki değişimlere göre farklı başa çıkma mekanizmaları geliştirdiği düşünülmektedir. Değişimin çok sık ve hızlı yaşandı̆̆1 toplumlarda bilişsel kapalılık ihtiyacının yüksek olmasının değişimle başa çıkma mekanizmalarını olumsuz 
etkilediği söylenebilir (Kruglanski, Pierro, Higgins ve Capozza, 2007). Değişimin hızlı olmasının olağan bir durum olarak değerlendirilmesi sistemi meşrulaştırma sürecindeki bilişsel ihtiyaçların rolünü etkilediği düşünülmektedir. Çalışmada sistemi meşrulaştırma ve bilişsel kapalılık ihtiyacı arasında beklendiği gibi olumlu bir ilişki olduğu gözlenmiştir (Jost, 2017). Sistemi meşrulaştırmanın belirsizliği azaltmak için epistemik ihtiyaçlarla motive edildiği fikriyle ve değişimle başa çıkma mekanizmalarının bir etkisinin olup olmadığı ileriye dönük çalışmalarda incelenmelidir.

Sistemi meşrulaştırma eğiliminin açıklanmasında sağ kanat yetkeciliği ve sosyal baskınlık yönelimi iki farklı motivasyon olarak ikili süreç modeli kapsamında ele alınmıştır (Duckitt ve Sibley, 2010; Jost ve ark., 2003a). Bu çalışmada da, sağ kanat yetkeciliği ve sosyal baskınlık yönelimi değişkenlerinin sistemi meşrulaştırma eğilimi üzerindeki yordayıc1 etkileri incelenmiştir. Elde edilen bulgular çalışmanın hipotezlerini doğrular şekilde, sağ kanat yetkeciliğinin ve sosyal baskınlık yöneliminin yüksek olmasının sistemi meşrulaştırma eğilimini olumlu yönde yordadığını göstermiştir. İkili süreç modeli kapsamındaki sağ kanat yetkeciliğinin yordayıcı etkisi dünyadaki tehlike ve tehditlere yönelik algıları güçlendirmeye, sosyal düzenin desteklenmesine ve güvenlik eğilimini arttırmasına yönelik etkilerle açıklanabilir (Schwartz ve Boehnke, 2004). Daha önce gerçekleştirilen çalışmalarda elde edilen bulguları (Altemeyer, 1998, Jost ve ark., 2003a) destekler şekilde sağ kanat yetkeciliğinin, otoritenin varlığının sorgusuz biçimde kabul edilmesi ve mevcut sistemin meşrulaştırılması üzerinde etkili olduğunu göstermiştir. Sağ kanat yetkeciliğin sistemi meşrulaştırma eğilimi üzerindeki etkisinin temeliyse sistemde varolan statükoyu koruma eğilimine dayandırılabilir. Dolayısıyla sistemin korunup devamlılı̆̆ının sağlanması eğilimi belirsizliğe ve varoluşa ilişkin kaygıların azalmasına katkıda bulunabilir (Jost ve ark., 2009b: 227). Sosyal baskınlık yöneliminin sistemi meşrulaştırma eğilimine olumlu etkisi ise dünya, güç mücadelesi ve rekabetin yoğun olarak yer aldığ1 bir ortam olduğu için hiyerarşinin kabul edilip eşitsizliğin meşrulaştırılmasına ilişkin tutumların onaylanmasıyla bağlantılıdır (Sidanius, Pratto, van Laar ve Levin, 2004). Çalışma bulguları ele alındığında sağ kanat yetkeciliğinin sosyal baskınlık yönelimine göre sistemi meşrulaştırma eğilimi üzerinde daha güçlü bir yordayıc1 etkisi olduğu söylenebilir. Bu durum sağ kanat yetkeciliğinin sosyal muhafazakarlığı, sosyal baskınlık yöneliminin ise ekonomik muhafazakarlı̆g1 yordaması (Jost ve ark., 2009a; Sibley, Wilson ve Duckitt, 2007) gibi bu iki değişkenin farklı yapıları farklı düzeylerde etkileme durumlarıyla ilişkili olarak açıklanabilir. Ayrıca, sağ kanat yetkeciliği ve sosyal baskınlık yöneliminin sistemi meşrulaştırma gibi sosyopolitik davranışlara ilişkin yapıların yordanmasında birlikte kullanıldığında diğer değişkenlere göre daha güçlü yordayıcılar oldukları bilinmektedir. Bunun nedeni olarak erken gelişim döneminde cezalandırıcı ve katı bir aile ortamında sosyalleşmenin bireyde uyum sağlayıcı bir kişilik özelliği, dünyayı da tehlikeli ve rekabet edilen bir yer olarak görme eğilimini (Jost ve ark.,2009b: 296) ve bilişsel kapalılık ihtiyacını arttırdığ1 düşünülmektedir.

Bu çalışmanın sonuçları bireyin mevcut sistemi meşrulaştırması sürecinde rol oynayan bilişsel yap1 ve sosyal tutumların etkisini vurgulamaktadır. Buna göre bilişsel kapalılık ihtiyacının, sağ kanat yetkeciliğinin ve sosyal baskınlık yöneliminin sistemi meşrulaştırma eğilimi üzerinde yordayıı etkileri olduğu gözlenmiştir. Öte yandan kuramsal çerçeveyle uyumlu şekilde sistemi meşrulaştırma eğilimlerine etki eden sosyal tutumlar olarak ele alınan sağ kanat yetkeciliği ve sosyal baskınlık yöneliminin, bilişsel yapı olarak ele alınan bilişsel kapalılık ihtiyacının güçlü yordayıcılar olduğu ortaya konulmuştur. Bu durum sosyal tutumların erken yaşlarda gelişen yapılar olarak sistemi meşrulaştırma gibi eğilimleri yordamada daha etkin olmalarıyla ilişkilendirilmektedir. Ayrıca sistemi meşrulaştırma eğilimleriyle cinsiyet, siyasi ve dini

Border Crossing 
yönelimlerin ilişkisi de çalışma bulgularıyla ortaya konulmuştur. Bu çalışmada, ülkemizde sistemi meşrulaştırma eğilimini inceleyen diğer çalışmalardan farklı olarak bilişsel yapı ve sosyal tutumların etkisi birlikte ele alınmıştır. Ancak çalışmanın bir takım sınırlılıkları da bulunmaktadır. Bunlardan ilki, çalışmanın kesitsel bir deseni olmasından dolayı değişkenler arası neden sonuç ilişkilerinin ortaya konmasının güçlügüüür. Ayrıca, çalışmada elde edilen verilerin tümünün öz bildirime dayalı ölçüm araçları ile sağlanması bir diğer sınırlılık olarak ifade edilebilir. Bu bakımdan çalışmada yer alan değişkenlerin daha objektif değerlendirmelere olanak sağlayan ölçüm araçları ile değerlendirilmesinin faydalı olacağ1 düşünülmektedir. Yapılacak yeni araştırmalarda sistemi meşrulaştırma eğilimi ile bilişsel yapılar ve sosyal tutumlar arasındaki ilişkilere arabuluculuk eden değişkenlerin incelenmesinin de sistemi meşrulaştırma eğilimine etki eden yapıların daha iyi anlaşılmasına katkı sağlayacağ1 düşünülmektedir.

Tablo 1. Değişkenler Arası Korelasyonlar

$\begin{array}{llllllllllllllll}\text { Değişkenler } & \text { Ort } & \mathbf{S} & \mathbf{1} & \mathbf{2} & \mathbf{3} & \mathbf{4} & \mathbf{5} & \mathbf{6} & \mathbf{7} & \mathbf{8} & \mathbf{9} & \mathbf{1 0} & \mathbf{1 1} & \mathbf{1 2} & \mathbf{1 3} \\ \text { 1.Siyasi Eğilim } & 3.85 & 1.43 & 1 & & & & & & & & & & \\ \text { 2.Dini Eğilim } & 4.49 & 1.40 & .46^{* *} & 1 & & & & & & & & & \\ \text { 3.Sistemi Meşrulaştırma } & 3.71 & 92 & .25^{* *} & 18^{* *} & 1 & & & & & & & & \\ \text { 4.Bilişsel Kapalılık } & 4.46 & 45 & .07 & 12^{* *} & 11^{*} & 1 & & & & & & & \\ \text { 5. Düzen Tercihi } & 4.72 & 75 & .03 & 15^{* *} & 04 & 75^{* *} & 1 & & & & & & \\ \text { 6.Belirsizlikten Rahatsızlık } & 4.67 & 63 & .02 & 05^{* *} & 11^{*} & 70^{* *} & 37^{* *} & 1 & & & & & \\ \text { 7. Tahmin İhtiyac1 } & 4.58 & 66 & .04 & 08^{*} & 05 & 71^{* *} & 43^{* *} & 40^{* *} & 1 & & & & \\ \text { 8.Dar Görüşlülük } & 3.37 & 72 & .06 & 10^{*} & 06 & 08^{*} & 51^{* *} & 45^{* *} & 30^{* *} & 1 & & & \\ \text { 9.Kararlılık } & 3.70 & 83 & .23^{* *} & 04 & 13^{* *} & 31^{* *} & 07 & 08^{*} & 02 & 09^{*} & 1 & & \\ \text { 10.Sağ Kanat Yetkecilik } & 5.63 & 89 & .02 & 05 & 15^{* *} & 09^{*} & 07 & 18^{* *} & 04 & 16^{* *} & 17^{* *} & 1 & & \\ \text { 11. Yüksek Düzey SKY } & 4.96 & 1.70 & .28^{* *} & 30^{* *} & 40^{* *} & 11^{*} & 14^{* *} & 12^{* *} & 11^{*} & 08 & -.18^{* *} & 69^{* *} & 1 \\ \text { 12. Düşük Düzey SKY } & 5.35 & 1.51 & -.38^{* *} & -.35^{* *} & -.37^{* *} & 04 & -.06 & -.10^{* *} & -.03 & -.10^{*} & 05 & 26^{* *} & -.48^{* *} & 1 \\ \text { 13.Toplumsal Baskınlık } & 3.11 & 92 & 18^{* *} & 01 & 31^{* *} & 23^{* *} & 14^{* *} & 17^{* *} & 12^{* *} & 20^{* *} & 12^{* *} & 10^{*} & 29^{* *} & -.23^{* *} & 1 \\ & & & & & & & & & & & & & & \end{array}$

Tablo 2. Sistemi Meşrulaştırma Eğilimini Yordayıcı Model: Regresyon Katsayıları ve Model İstatistikleri

\begin{tabular}{|c|c|c|c|c|c|c|c|c|c|}
\hline & Model & & & Model 2 & & & Model & & \\
\hline Değişkenler & B & SE & $\beta$ & $\mathrm{B}$ & $\mathrm{SE} b$ & $\beta$ & B & $\mathrm{SE} b$ & $\beta$ \\
\hline Yaş & -.04 & .059 & -.04 & -.03 & .06 & -.03 & -.01 & .05 & -.01 \\
\hline Erkek & 3.16 & .923 & $.17 * *$ & 2.83 & .91 & $.15^{* *}$ & .37 & .82 & .02 \\
\hline Bekar & -2.32 & 1.11 & $-.12 *$ & -2.35 & 1.08 & $-.12 *$ & -1.95 & .94 & $-.10^{*}$ \\
\hline Dul/boşanmış & 2.95 & 3.04 & .05 & 3.27 & 2.94 & .05 & 2.42 & 2.54 & .04 \\
\hline Türkiye'de köy & -11.34 & 8.81 & -.30 & -13.11 & 8.51 & -.35 & -9.01 & 7.36 & -.24 \\
\hline Türkiye'de ilçe & -9.93 & 8.80 & -.30 & -11.96 & 8.50 & -.36 & -7.71 & 7.36 & -.23 \\
\hline Türkiye'de şehir & -12.48 & 8.68 & -.65 & -14.08 & 8.40 & -.73 & -9.77 & 7.26 & -.51 \\
\hline Türkiye'de büyükşehirden & -14.24 & 8.69 & -.66 & -15.94 & 8.41 & -.74 & -11.23 & 7.28 & -.52 \\
\hline Siyasi eğilim & 1.71 & .36 & $.26^{* *}$ & 1.76 & .36 & $.26 * *$ & .80 & .32 & $.12^{*}$ \\
\hline Dini eğilim & 1.08 & .35 & $.17^{* *}$ & .98 & .35 & $.15^{* *}$ & .27 & .32 & .04 \\
\hline Düzen tercihi & & & & .56 & .52 & $.12^{*}$ & 1.06 & .62 & $.08^{*}$ \\
\hline Belirsizlikten rahatsızlik & & & & 2.57 & .83 & $.17 * *$ & 2.05 & .73 & $.14^{* *}$ \\
\hline Tahmin ihtiyac1 & & & & .65 & .55 & $.15^{*}$ & 1.16 & .66 & $.08^{*}$ \\
\hline Kararlılık & & & & 1.95 & .54 & $.17 * *$ & 1.02 & .48 & $-.09 *$ \\
\hline Dar görüşlülük & & & & .11 & .75 & .01 & .94 & .65 & .07 \\
\hline Yüksek sağ kanat yetkeciliği & & & & & & & .12 & .03 & $.18^{* *}$ \\
\hline Düşük sağ kanat yetkeciliği & & & & & & & -.19 & .04 & $-.27 * *$ \\
\hline Toplumsal baskınlık yönelimi & & & & & & & .14 & .03 & $.23^{* *}$ \\
\hline $\mathrm{R}^{2}$ & $.20 * *$ & & & $.25 * *$ & & & $.45^{* *}$ & & \\
\hline$\overline{\mathrm{R}^{2} \text { Change }}$ & $.20 * *$ & & & $.05^{* *}$ & & & $.20 * *$ & & \\
\hline F for $\mathrm{R}^{2} \Delta$ & $8.34 * *$ & & & $10.17 * *$ & & & $19.59^{* *}$ & & \\
\hline
\end{tabular}




\section{Kaynakça}

Altemeyer, B. (1996). The authoritarian specter. Cambridge, MA: Harvard University Press.

Altemeyer, B. (1998). The other "authoritarian personality". Advances in Experimental Social Psychology, 30, 4792.

Altemeyer, B. (2003). What happens when authoritarians inherit the earth? A simulation. Analyses of Social Issues and Public Policy, 3(1), 161-169.

Canetti-Nisim, D. ve Beit-Hallahmi, B. (2007). The Effects of Authoritarianism, Religiosity, and" New Age" Beliefs on Support for Democracy: Unraveling the Strands. Review of Religious Research, 48(4) 369-384.

Chirumbolo, A. (2002). The relationship between need for cognitive closure and political orientation: The mediating role of authoritarianism. Personality and Individual Differences, 32(4), 603-610.

Chirumbolo, A. ve Areni, A. (2010). Job insecurity influence on job performance and mental health: Testing the moderating effect of the need for closure. Economic and Industrial Democracy, 31(2), 195-214.

Corr, P. J., Hargreaves-Heap, S., Tsutsui, K., Russell, A. ve Seger, C. (2013). Personality and social attitudes: Evidence for positive-approach motivation. Personality and Individual Differences, 55(7), 846-851.

Calogero, R. M., Bardi, A., ve Sutton, R. M. (2009). A need basis for values: Associations between the need for cognitive closure and value priorities. Personality and Individual Differences, 46(2), 154-159.

Cuddy, A. J., Fiske, S. T. ve Glick, P. (2004). When professionals become mothers, warmth doesn't cut the ice. Journal of Social Issues, 60(4), 701-718.

Cutright, K. M., Wu, E. C., Banfield, J. C., Kay, A. C. ve Fitzsimons, G. J. (2011). When your world must be defended: Choosing products to justify the system. Journal of Consumer Research, 38(1), 62-77.

Day, M. V., Kay, A. C., Holmes, J. G. ve Napier, J. L. (2011). System justification and the defense of committed relationship ideology. Journal of Personality and Social Psychology, 101 (2), 291-306.

Dirilen-Gumus, O. (2011). Differences in system justification with respect to gender, political conservatism, socio-economic status and religious fundamentalism. Procedia-Social and Behavioral Sciences, 30, 2607-2611.

Duck, R. J. ve Hunsberger, B. (1999). Religious orientation and prejudice: The role of religious proscription, right-wing. The International Journal for the Psychology of Religion, 9(3), 157-179.

Duckitt, J. ve Sibley, C. G. (2010). Personality, Ideology, Prejudice, and Politics: A Dual-Process Motivational Model. Journal of Personality, 78(6), 1861-1894.

Duckitt, J. ve Bizumic, B. (2013). Multidimensionality of Right-Wing Authoritarian Attitudes: Authoritarianism-Conservatism-Traditionalism. Political Psychology, 34(6), 841-862.

Duckitt, J., Wagner, C., Du Plessis, I. ve Birum, I. (2002). The psychological bases of ideology and prejudice: testing a dual process model. Journal of Personality and Social Psychology, 83(1), 75-93.

Duriez, B. (2003). Vivisecting the religious mind: Religiosity and motivated social cognition. Mental Health, Religion \& Culture, 6(1), 79-86.

Duriez, B. ve Soenens, B. (2009). The intergenerational transmission of racism: The role of right-wing authoritarianism and social dominance orientation. Journal of Research in Personality, 43(5), 906-909.

Feygina, I., Jost, J. T., ve Goldsmith, R. E. (2010). System justification, the denial of global warming, and the possibility of "system-sanctioned change". Personality and social psychology bulletin, 36(3), 326-338.

Fu, J. H. Y., Morris, M. W., Lee, S. L., Chao, M., Chiu, C. Y. ve Hong, Y. Y. (2007). Epistemic motives and cultural conformity: need for closure, culture, and context as determinants of conflict judgments. Journal of Personality and Social Psychology, 92(2), 191-207.

Furseth, I., ve Repstad, P. (2011). Din Sosyolojisine Giriş. Ankara: Birleşit Yayınevi.

Francis, L. J. (2001). Christianity and dogmatism revisited: A study among fifteen and sixteen year olds in the United Kingdom. Religious Education, 96(2), 211-226.

Göregenli, M. (2004). Şiddet Kötü Muamele ve İşkenceye İlişkin Değerlendirmeler Tutumlar ve Deneyimler: (İzmir Araştırması) İzmir Barosu Yayınları.

Göregenli, M. (2013). Ayrımcılı̆̆ın Meşrulaştırılması. M. Çmar (Ed.), Medya ve Nefret Söylemi, (39-54). İstanbul, Bilgi Üniversitesi.

Güldü, Ö. (2011). Sağ Kanat Yetkeciliği Ölçeği: Uyarlama Çalışması. Ankara Üniversitesi Sosyal Bilimler Enstitïsü Dergisi, 2(2), 27-51.

Güldü, Ö. ve Kart, M. E. (2009). Toplumsal cinsiyet rolleri ve siyasal tutumlar: Sosyal psikolojik bir değerlendirme. Ankara Üniversitesi SBF Dergisi, 64(3), 97-116.

\section{Border Crossing}


Hasta, D. ve Dönmez, A. (2009). Yetkecilik ve Bilişsel Karmaşıklık Düzeyi ile Siyasal İdeoloji Arasındaki İlişki. Türk Psikoloji Dergisi, 24(64), 19-29.

Henry, P. J. ve Saul, A. (2006). The Development of System Justification in the Developing World. Social Justice Research, 19(3), 365-378.

Jolley, D., Douglas, K. M., ve Sutton, R. M. (2018). Blaming a few bad apples to save a threatened barrel: The system-justifying function of conspiracy theories. Political Psychology, 39(2), 465-478.

Jost, J. T. (1995). Negative illusions: Conceptual clarification and psychological evidence concerning false consciousness. Political Psychology, 16, 397-424.

Jost, J. T. (2006). The end of the end of ideology. American Psychologist, 61(7), 651-670.

Jost, J. T. (2017). Ideological asymmetries and the essence of political psychology. Political psychology, 38(2), $167-208$.

Jost, J. T. (2020). A theory of system justification. Harvard University Press.

Jost, J. T. ve Banaji, M. R. (1994). The role of stereotyping in system-justification and the production of false consciousness. British Journal of Social Psychology, 33(1), 1-27.

Jost, J. T. ve Thompson, E. P. (2000). Group-based dominance and opposition to equality as independent predictors of self-esteem, ethnocentrism, and social policy attitudes among African Americans and European Americans. Journal of Experimental Social Psychology, 36(3), 209-232.

Jost, J. T. ve Hunyady, O. (2002). The psychology of system justification and the palliative function of ideology. European Review of Social Psychology, 13,111-153.

Jost, J. T., Blount, S., Pfeffer, J. ve Hunyady, G. (2003b). Fair market ideology: Its cognitive-motivational underpinnings. Research in Organizational Behavior, 25, 53-91.

Jost, J. T., Banaji, M. R. ve Nosek, B. A. (2004). A decade of system justification theory: Accumulated evidence of conscious and unconscious bolstering of the status quo. Political Psychology, 25(6), 881-919.

Jost, J. T. ve Hunyady, O. (2005). Antecedents and consequences of system-justifying ideologies. Current Directions in Psychological Science, 14(5), 260-265.

Jost, J. T. ve Kay, A. C. (2005). Exposure to benevolent sexism and complementary gender stereotypes: consequences for specific and diffuse forms of system justification. Journal of Personality and Social Psychology, 88(3), 498-509.

Jost, J. T., Nosek, B. A., \& Gosling, S. D. (2008a). Ideology: Its Resurgence in Social, Personality, and Political Psychology. Perspectives on Psychological Science, 3(2), 126-136.

Jost, J. T., Wakslak, C. ve Tyler, T. R. (2008b). System justification theory and the alleviation of emotional distress: Palliative effects of ideology in an arbitrary social hierarchy and in society. Justice: Advances in Group Processes, 25, 181-211.

Jost, J. T., Ledgerwood, A. ve Hardin, C. D. (2008c). Shared reality, system justification, and the relational basis of ideological beliefs. Social and Personality Psychology Compass, 2(1), 171-186.

Jost, J. T., Federico, C. M. ve Napier, J. L. (2009a). Political ideology: Its structure, functions, and elective affinities. Annual Review of Psychology, 60, 307-337.

Jost, J. T., Kay, A. C. ve Thorisdottir, H. (Eds.). (2009b). Social and psychological bases of ideology and system justification. Oxford, UK: Oxford University Press.

Jost, J. T., ve Andrews, R. (2011). System justification theory. In D. Christie (Ed.), The encyclopedia of peace psychology(1092-1096). West Sussex, United Kingdom: Wiley-Blackwell.

Jost, J. T., Pietrzak, J., Liviatan, I., Mandisodza, A. N., ve Napier, J. L. (2008). System justification as conscious and nonconscious goal pursuit. In J. Y. Shah \& W. L. Gardner (Eds), Handbook of motivation science (591-605). The Guilford Press

Jost, J. T., Glaser, J., Kruglanski, A. W. ve Sulloway, F. J. (2003a). Political conservatism as motivated social cognition. Psychological Bulletin, 129(3), 339-375.

Jost, J. T., Hawkins, C. B., Nosek, B. A., Hennes, E. P., Stern, C., Gosling, S. D., ve Graham, J. (2014). Belief in a just God (and a just society): A system justification perspective on religious ideology. Journal of Theoretical and Philosophical Psychology, 34, 56-81.

Karaçanta, H. (2002). Universite ögrencilerinin sosyal baskınlı, yönelimi ve başka baz̧ deģ̆̈skenler açısından karşılaştırlması. Yayınlanmamış Doktora Tezi, Ankara Üniversitesi Sosyal Bilimler Enstitüsü.

Karaçay, G. (2011). İşsiz bireylerde yașam doyumu: Eğitim, dini duygulanım ve sistemi meşrulaștırma bakımından bir inceleme (Master's thesis, Sosyal Bilimler Enstitüsü). 
60 Bilişsel Yapımn ve Sosyal Tutumlarn Sistemi Meșrulaştırma Eğilimine Etkisi

Kay, A. C. ve Jost, J. T. (2003). Complementary justice: Effects of -Poor but Happy and Poor but Honest stereotype exemplars on system justification and implicit activation of the justice motive. Stanford University Journal of Personality and Social Psychology, 85, 823-837.

Kay, A. C., Jimenez, M. C. ve Jost, J. T. (2002). Sour grapes, sweet lemons, and the anticipatory rationalization of the status quo. Personality and Social Psychology Bulletin, 28(9), 1300-1312.

Kay, A. C., Czaplinski S. ve Jost, J. T. (2009). Left-right ideological differences in system justification following exposure to complementary versus noncomplementary stereotype exemplars. European Journal of Social Psychology, 39, 290-298.

Kay, A. C., Gaucher, D., Napier, J. L., Callan, M. J. ve Laurin, K. (2008). God and the government: testing a compensatory control mechanism for the support of external systems. Journal of Personality and Social Psychology, 95(1), 18-35.

Kossawska, M. ve Van Hiel, A. (2003). The relationship between need for closure and conservative beliefs in Western and Eastern Europe. Political Psychology, 24(3), 501-518.

Kruglanski, A. W. (2012). Lay epistemic theory. In P. A. M. Van Lange, A. W.

Kruglanski, A. W. ve Ajzen, I. (1983). Bias and error in human judgment. European Journal of Social Psychology, 13(1), 1-44.

Kruglanski, A. W., ve Webster, D. M. (1996). Motivated closing of the mind:" Seizing" and" freezing.". Psychological review, 103(2), 263.

Kruglanski, A. W., Pierro, A., Higgins, E. T. ve Capozza, D. (2007). "On the Move" or "Staying Put": Locomotion, Need for Closure, and Reactions to Organizational Change1. Journal of Applied Social Psychology, 37(6), 1305-1340.

Lerner, M. J. (1980). The belief in a just world: A fundamental delusion. New York: Plenum Press.

Liviatan, I., ve Jost, J. T. (2011). Special Issue: System Justification Theory: Motivated Social Cognition in the Service of the Status Quo. Social Cognition, 29(3), 231-237.

Matthews, M., Levin, S. ve Sidanius, J. (2009). A longitudinal test of the model of political conservatism as motivated social cognition. Political Psychology, 30(6), 921-936.

Mumford, M. D., Bedell-Avers, K. E., Hunter, S. T., Espejo, J., Eubanks, D., ve Connelly, M. S. (2008). Violence in Ideological and Non-Ideological Groups: A Quantitative Analysis of Qualitative Data. Journal of Applied Social Psychology, 38(6), 1521-1561.

Okumuş, E. (2003). Toplumsal Eşitsizliklerin Meşruiyet Kazanmasında Din. CÜ Sosyoloji Araștırmaları Dergisi, (1), 51-68.

Onraet, E., Hiel, A. ve Cornelis, I. (2013). Threat and Right-Wing Attitudes: A Cross-National Approach. Political Psychology, 34(5), 791-803.

Perry, R. ve Sibley, C. G. (2010). Dangerous and competitive schemas: A new frequency estimation index of the dual process model's social worldviews component. Personality and Individual Differences, 49(8), 983988.

Pierro, A. ve Kruglanski, A. W. (2008). "Seizing and freezing" on a significant-person schema: Need for closure and the transference effect in social judgment. Personality and Social Psychology Bulletin, 34(11), 14921503.

Poteat, V. P. ve Spanierman, L. B. (2010). Do the ideological beliefs of peers predict the prejudiced attitudes of other individuals in the group?. Group Processes and Intergroup Relations, 13, 495-514.

Pratto, F., Sidanius, J. ve Levin, S. (2006). Social dominance theory and the dynamics of intergroup relations: Taking stock and looking forward. European Review of Social Psychology, 17(1), 271-320.

Roets, A. ve Van Hiel, A. (2007). Separating ability from need: Clarifying the dimensional structure of the need for closure scale. Personality and Social Psycbology Bulletin, 33(2), 266-280.

Roets, A. ve Soetens, B. (2010). Need and ability to achieve closure: Relationships with symptoms of psychopathology. Personality and Individual Differences, 48(2), 155-160.

Roets, A. ve Van Hiel, A. (2011). Item selection and validation of a brief, 15-item version of the Need for Closure Scale. Personality and Individual Differences, 50(1), 90-94.

Rudman, L. A. ve Goodwin, S. A. (2004). Gender differences in automatic in-group bias: Why do women like women more than men like men?. Journal of Personality and Social Psychology, 87(4), 494-509.

Sibley, C. G., Wilson, M. S. ve Duckitt, J. (2007). Antecedents of men's hostile and benevolent sexism: The dual roles of social dominance orientation and right-wing authoritarianism. Personality and Social Psychology Bulletin, 33(2), 160-172.

\section{Border Crossing}


Sidanius, J., ve Pratto, F. (1999). Social dominance: An intergroup theory of social hierarchy and oppression. New York, NY: Cambridge University Press.

Sidanius, J., Pratto, F. ve Bobo, L. (1994). Social dominance orientation and the political psychology of gender: A case of invariance?. Journal of Personality and Social Psychology, 67(6), 998-1011.

Sidanius, J., Levin, S., Liu, J. H. ve Pratto, F. (2000). Social dominance orientation and thepolitical psychology of gender: An extension and cross-cultural replication. European Journal of Social Psychology, 30, 41-67.

Sidanius, J., Pratto, F., van Laar, C. ve Levin, S. (2004). Social dominance theory: Its agenda and method. Political Psychology, 25, 845-880.

Schwartz, S. H., ve Boehnke, K. (2004). Evaluating the structure of human values with confirmatory factor analysis. Journal of Research in Personality, 38(3), 230-255.

Şeker, B. D. ve Akman, E. (2015). Bilişsel Kapalılık İhtiyacı Ölçeğinin Türkçe 'ye Uyarlanması, Güvenirlik ve Geçerlik Analizi. Türk Psikoloji Yazılar, 18(35): 51-63.

Sönmez, B. ve Hasta, D. (2021). Dindarlık ile Politik Güven Arasındaki İlişkide Yetkecilik ve Sistemi Meşrulaştırmanın Aracı Rolü. Türk Psikoloji Dergisi, 36(87), 1-19.

Van Hiel, A. ve Mervielde, I. (2004). Openness to experience and boundaries in the mind: Relationships with cultural and economic conservative beliefs. Journal of Personality, 72(4), 659-686.

Van Hiel, A., Pandelaere, M. ve Duriez, B. (2004). The impact of need for closure on conservative beliefs and racism: Differential mediation by authoritarian submission and authoritarian dominance. Personality and Social Psychology Bulletin, 30(7), 824-837.

Wakslak, C. J., Jost, J. T., Tyler, T. R. ve Chen, E. S. (2007). Moral outrage mediates the dampening effect of system justification on support for redistributive social policies. Psychological Science, 18(3), 267-274.

Webster, D. M. ve Kruglanski, A. W. (1994). Individual differences in need for cognitive closure. Journal of Personality and Social Psychology, 67(6), 1049-1062.

Yıldırım, N. (2010). Sivil toplum kuruluşu gönüllïlerinin adil dünya inançlar, sosyal baskınlı, yönemlimleri ve sistemi meşru algzlama düzeyleri. Mersin Üniversitesi Yüksek Lisans Tezi.

Yıldırım, N. ve Akgün, S. (2013). Sivil Toplum Kuruluşu Gönüllülerinin Sosyal Sistemin Meşruiyetine İlişkin Algıları, Adil Dünya İnançları ve Sosyal Baskınlık Yönelimleri. Toplum ve Sosyal Hiæ̌met, 24(1), 115-128.

\section{Summary}

System justification motivation as a concept related to ideological motivations and a psychological adaptation mechanism helps individuals cope with existential and epistemic threats in a social system that is not legitimate, just, and stable (Kay et al., 2008). The concept of society existing social and economic system legitimation of hierarchical structure simplifies maintenance of the existing structure for the protection of the thoughts. System justification, a psychological process, is described as legitimization with the current social, economic, and political system conditions. According to the system justification theory was developed by Jost and Banaji (1994), the concept of the system encompasses all social arrangements such as family, social and political groups, etc. This theory tries to describe why individuals pursue the social system that harms the individuals or groups. System justification theorists explain how individuals justify the existing social system with such factors as "pursuing cognitive consistency, reducing the uncertainty resuming conservatism and fear of equality" (Cutright et al., 2011). Political conservatism, social dominance orientation, right-wing authoritarianism, and the need for cognitive closure are addressed as system justifying structures (Jost, Glaser, Kruglanski, and Sulloway, 2003a). In this study, the need for cognitive closure as a cognitive structure, right-wing authoritarianism, and social dominance orientation as social attitudes (Duckitt and Sibley, 2010) are considered the system justifying variables.

These variables are associated with the epistemic and social needs of the individuals, and the system justification is supposed to be related to meet these needs (Göregenli, 2013). Thus, the epistemic needs of the individuals should be considered when assessing the system justification tendencies. Justifying a consistent and predictable social system by individuals is 
supposed to constitute a palliative effect that provides a positive affect in general (Wakslak et al., 2007). Kruglanski and Ajzen's (1983) need for cognitive closure concept is a frequently used theory while explaining one's epistemic needs and motivations. The need for cognitive closure is defined as a strong motive for any definite information on a given topic contrary to confusion and uncertainty, influencing the judgments and decisions of individuals about the social world (Roets ve Van Hiel, 2007). Individuals with a high need for cognitive closure give importance to stability; have a low tolerance for ambiguity and a motivation to reach quick decisions (Chirumbolo ve Areni, 2010; Roets ve Soetens, 2010). In addition, the need for cognitive closure is linked to the concepts that are ideology-related attitudes, judgments, and tendencies (Jost et al., 2009).

The main aim of this study is to examine the effect of the need for cognitive closure, rightwing authoritarianism, and social dominance orientation which are evaluated as the cognitive structure and social attitudes on the system justification motivation. Right-wing authoritarianism and social dominance orientation are two major factors to understand the underlying motives of system justification which are identified with the dual-process model developed by Duckitt, Wagner, Du Plessis, and Birum (2002). According to the dual-process model, right-wing authoritarianism (Altemeyer, 2003) provides perceiving the world as a place filled with dangers and threats and emphasizes the requirement of the sense of social order and security in the community (Schwartz and Boehnke, 2004). On the other hand, social dominance orientation (Pratto, Sidanius, van Laar and Levin, 2004) provides individuals an evaluation of the social world as a full of struggle for power and competition. The hypotheses which will test for the study are listed below.

1. Participants' system justification levels significantly differ from each other according to their gender, religious and political orientation.

2. Participants' need for cognitive closure, right-wing authoritarianism, and social dominance orientation positively predict their system justification levels.

\section{Method}

\section{Sample}

A total of $394(203=$ women, $191=$ men $)$ participants currently living in Manisa and surroundings, with the age range of 23 and $55(\mathrm{M}=33.67$; $\mathrm{SD}=9.3)$ took part in the study. 33.65 ( $\mathrm{S}=9.31$ ). Participants were asked to rate their own religious and political tendencies on a 7-point scale, and as a result, participants' religious tendencies averaged $4.66(\mathrm{~S}=1.50 ; 1$ $=$ no believer, 7 = many believers); and their political tendencies were found to be 3.85 on average $(\mathrm{S}=1.43 ; 1=$ extreme left, 7 = extreme right).

\section{Materials}

Demographic Information Form. Researchers developed this module to collect demographic background information from the participants to indicate their gender, marital status, age, income, religious and political orientation in the demographic information form.

System Justification Scale. System justification of the participants was measured with the adopted Turkish version (Yıldırım, 2010) of the system justification scale (Kay and Jost, 2003). 
A total score of system justification tendencies was calculated with the mean of 8 items, and in this study, it has a reliability of .82 .

Need for Cognitive Closure Scale. The need for cognitive closure was assessed with the adopted Turkish version (Şeker and Akman, 2015) of the need for cognitive closure scale (Webster and Kruglanski 1994). The need for closure scale was; preference for order, discomfort with ambiguity, predictability, closed-mindedness and decisiveness. In this study, subscales have reliability scores between .57 of .69 , and the scale has a reliability of .79 .

Right-Wing Authoritarianism Scale. The Turkish version of this scale (Güldü, 2011) was used to measure the authoritarianism levels of the participants, which were developed by Altemeyer (1996). The scale has two subscales as high right-wing authoritarianism (.81) and low right-wing authoritarianism scales (.77). The scale has a reliability score of .85 for this study.

Social Dominance Orientation Scale (SDOS). The Turkish form of the social dominance orientation scale (Karaçanta, 2002) was used to determine the level of individuals and groups' social dominance and superiority orientation developed by Sidanius et al. (1994). The scale consists of 16 items, and the reliability coefficient of the scale for this study was .80 .

\section{Procedure}

The scale was implemented voluntarily, and the personal information was not asked and administered face-to-face to the participants.

\section{Results}

\section{Findings Related to Correlation Analysis}

The results of the correlation analysis performed to determine the relationships between the variables in the study are shown in Table 1.

It is seen that legitimating the system is positively and significantly related to political opinion, religious belief, cognitive closure, right-wing authoritarianism, and social dominance. This finding shows that as the level of right-wing political view and belief increases, the level of legitimation of the system increases. Other relationships observed between variables are not significant.

\section{Influences on System Justification Motivation}

A hierarchical multiple regression analysis is conducted to identify the variables affecting the system justification motivation of the participants (Table 2 ). Table 2 indicates that in the first model, gender, marital status, political and religious orientation variables had an overall significant impact on system justification motivation levels $\left(\mathrm{R}^{2}=.18, \mathrm{~F}(11,371)=8.33, \mathrm{p}\right.$ $<.01)$. In the second regression model, the explanatory power increased to $23 \%\left(\mathrm{R}^{2}=.23\right.$, $\mathrm{F}(16,379)=8.17, \mathrm{p}<.01)$. Findings show that preference for order, discomfort with uncertainty, predictability, and decisiveness dimension scores of the cognitive closure need scale had a significant predictive effect on the model. It was found that the closed-mindedness sub-dimension did not have a significant effect on predicting the tendency to legitimize the system. The third regression model, including right-wing authoritarianism and social dominance orientation, explained $43 \%$ of the total variance in system justification motivation 
scores $\left(\mathrm{R}^{2}=.43, \mathrm{~F}(19,379)=15.84, \mathrm{p}<.01\right)$. Thus, the results revealed that system justification motivations are higher among those with high right-wing authoritarianism and social dominance orientation.

\section{Discussion}

This study, it was aimed to examine the cognitive structure and social attitude variables that are related to system justification motivation. The general purpose of this study is to investigate the structures that have predictor roles on the system justification motivation of the participants. In general, descriptive statistic results showed that participants' system justification motivations differ significantly in their gender, religious and political orientation levels. Additionally, the hierarchical regression model revealed that the need for cognitive closure has a strong predictive effect on the system justification motivation. On the basis that the need for cognitive closure is an effective predictor of the tendency to legitimize the system, it is thought that people have a desire to end the uncertainty experienced by using stereotypes shared by everyone in their daily information acquisition process. The underlying mechanism related to the need for cognitive closure might be the cognitive structures effective during the justification of an existing social system. Therefore, the relationship between the need for closure and the system justification motivation was generally significant.

The results also indicated that right-wing authoritarianism and social dominance orientation explains the $20 \%$ variance of the system justification motivation. Thus, the participants with higher right-wing authoritarianism and social dominance orientation have higher system justification motivations. Consistent with the dual-process model, the predictive roles of the right-wing authoritarianism and social dominance orientation on the system justification motivation could be explained with supportive role of the right wing authoritarianism for the maintenance of the social system and enhancing the need for security (Schwartz and Boehnke, 2004). The positive effect of the social dominance orientation on the system justification motivation could be related to the power struggles and competence in the social world, and these features could lead to approving justifying inequalities and accepting the status quo (Sidanius, Pratto, van Laar and Levin, 2004).

There are some limitations of this study, and one of the most important is the data was obtained using the cross-sectional method. Another limitation of the study was using a selfreporting method to measure all variables of the study. The summary finding of the current study emphasizes the role of cognitive structures and social attitudes on the system justification motivation of the individuals. Consistent with the literature, social attitudes, which are examined through right-wing authoritarianism and the social dominance orientation, are stronger predictors than the need for cognitive closure. A possible explanation for this difference might be that social attitudes develop at early ages, so these attitudes might be more associated with the system justification motivation. 